\title{
Microbiologically influenced corrosion in oil and gas industries:
}

\section{A review}

\author{
M.A.A. Khan, ${ }^{1}$ (1) * M. Hussain ${ }^{2}$ and F. Djavanroodi ${ }^{1}$ \\ ${ }^{1}$ Mechanical Engineering Department, College of Engineering, Prince Mohammad bin \\ Fahd University, Al Khobar 31952, Saudi Arabia \\ ${ }^{2}$ Mechanical Engineering Department, King Fahd University of Petroleum and Minerals, \\ Dhahran 31261, Saudi Arabia \\ *E-mail: $\underline{\text { mhan6@pmu.edu.sa }}$
}

\begin{abstract}
Microbial Corrosion or more commonly known as Microbiologically Influenced Corrosion (MIC) is of significant interest and importance to the oil and gas industry. Microorganisms such as sulphate reducing bacteria (SRB), sulphate oxidizing bacteria (SOB), Metal oxidizing and reducing bacteria are responsible of MIC, with SRB to be considered as major cause of MIC in pipeline systems. Reservoir souring, leakage in storage tanks, and equipment and pipeline failures are some of the key issues faced by this industry due to MIC. With $75 \%$ and $50 \%$ shares in the oil well failures and internal pipeline corrosion respectively, it has now become a prime area of research in terms of understanding the microbial species, their interactions with metals and other microorganisms, followed by detection, monitoring and control of MIC. This paper/project reviews the current understanding of MIC in oil and gas industry that has been developed through research activities over the recent past. Microorganisms associated with corrosion are introduced, after which the details of mechanisms involved in an MIC occurrence are presented. Conventional and advanced characterization, monitoring and inspections techniques for MIC are discussed in detail. Various methods for prevention and control are presented such as cleaning methods, use of biocides, coatings, proper material selection, and cathodic protection. Excerpts of case studies are included to provide the insights on how research is being conducted in the industry towards MIC occurrences. It is found that MIC is a function of a host of parameters which are common in oil and gas industries, making them extremely vulnerable to this severe form of corrosion.
\end{abstract}

Keywords: microbial corrosion, microorganisms, sulphate reducing bacteria, characterization, oil and gas.

Received: May 27, 2020. Published: February 2, 2021

doi: $\underline{10.17675 / 2305-6894-2021-10-1-5}$

\section{Introduction and background}

Corrosion is the destructive attack of a metal by its reaction with the environment [1], and it has always remained a key problem in oil and gas industries. The occurrence of corrosion is observed in all areas of this industry from exploration and production to transportation through pipeline systems. High impurity products in crude oil and natural gas such as 
Hydrogen Sulfide $\left(\mathrm{H}_{2} \mathrm{~S}\right)$, Carbon dioxide $\left(\mathrm{CO}_{2}\right)$ and free water are inherently corrosive due to which pipelines and associated component fittings experience corrosion when exposed to different environments and operating conditions [2]. Various forms of corrosion have been identified in oil and gas industries such as stress corrosion cracking (SCC), corrosion fatigue, high temperature corrosion, sweet corrosion, $\mathrm{H}_{2} \mathrm{~S}$ corrosion etc. Most of these forms are characterized by the source which drives corrosion in the system such as, SCC is caused by conjoint action of stress and corrosive environment, corrosion fatigue is observed in components subjected to cyclic loading in a corrosive environment, and sweet corrosion and $\mathrm{H}_{2} \mathrm{~S}$ corrosion are due to the presence of $\mathrm{CO}_{2}$ and $\mathrm{H}_{2} \mathrm{~S}$ in fluid compositions. Investigations on forms of corrosion reveled that it can also be derived from microorganisms and microbiological activities within a system, the form thus named as Microbiologically Influenced Corrosion (MIC). MIC and the way it affects corrosion have always been a matter of debate. For example, while acid production by bacteria is presumed to be one of the ways by which corrosion can be enhanced, some researchers [3] in their experience with aerobic Pseudomonas sp. have reported that acid production was not a major cause of corrosion, and others [4] have pointed out that the presence of bacteria was not "an important factor in the deterioration of steels". It seems that it is not always easy to come up with a clear, onceforever-true explanation of the impact of bacteria on corrosion. As a matter of fact, such relatively confusing outcomes have helped make MIC a puzzle to some and to others an "industrial joke" that is used when there is no other explanation for the failure [5].

\section{Why is MIC important?}

Microbiologically influenced corrosion (MIC) is of significant interest and importance to oil and gas industry [6], and is defined as "An electrochemical process in which microorganisms can initiate, facilitate and accelerate the corrosion reaction by the interaction of three components that make up this system: metal, solution, and micro-organisms [7]". The phenomena is similar to the one in a typical corrosion occurrence where an electron donor, an electron acceptor, an electrolyte (water), an energy source and a carbon source are available together with the micro-organisms to initiate MIC. Owing to the fact that it can exist in all environments (seawater, soil, atmosphere), it accounts for more than $75 \%$ of the corrosion in productive oil wells, and for more than $50 \%$ of the failures in pipeline systems [8]. On the basis of Gross National Product (GNP), annual MIC-related industrial loss in Australia, for instance, is estimated to be AUD\$ 6b [13] (about US\$ 5b). A 1954 estimate of MIC loss in buried pipelines, for instance, puts a figure between 0.5 and 2.0 billion US dollars a year, a figure that can only have increased since then [9]. Also, MIC is estimated to cost over US\$ 100 million per annum to oil and gas industry [10], and responsible for 20-30\% of all internal pipeline corrosion costs [8]. Biocorrosion has been estimated to be responsible of $10 \%$ of corrosion cases in the UK [11]. MIC has caused a lifetime reduction of flow lines in Western Australia from the designed $>20$ years to less than 3 years. In addition, microbial corrosion has been addressed as one of the major causes of corrosion problems of underground pipelines [12]. Sulphate- 
reducing bacteria (SRB), a notorious corrosion-enhancing bacteria, has been reported to be responsible for extensive corrosion of drilling and pumping machinery and storage tanks [13]. SRB have also been reported to contaminate crude oil, resulting in increased sulfur levels of fuels. These bacteria are important in secondary oil recovery processes, where bacterial growth in injection waters can plug machinery used in these processes. It has also been suggested that these micro-organisms may play a role in the biogenesis of oil hydrocarbons [9]. With all essential elements needed for microbial life such as water, carbon source, electron donor, and electron acceptor, the oil and gas transporting systems are extremely vulnerable to MIC. Moreover, the presence of sulphur, nitrogen, carbon and phosphorus in the process feed promotes microbial life within these systems $[14,15]$.

Although the electrochemical nature of corrosion remains same for MIC, the contribution of microorganisms in the process brings a number of unique features, the most important being the modification of metal-solution interface by Biofilm formation. Biofilm is a thin film produced by the bacteria when attached on the metallic surfaces. The time of biofilm formation could be minutes to hours and is a function of the environment where the metal is immersed. A stage wise development of biofilm is presented in Figure 1. Biofilm formation begins with the formation of a conditioning film and at this point the bacteria are in their planktonic state as shown in Figure 1(a). Followed by this the bacteria starts to form colonies on the surface of conditioning film as in Figure 1(b) and become sessile bacteria by excreting exopolysaccharidic substances (EPS) which anchors the cells to the surface [7]. Different species of sessile bacteria continue to replicate on the metal surface and start to act like a net as depicted in Figure 1(c) and (d), which traps more and more particles and increases the thickness of biofilm. In addition to increased thickness, the close relationship between micro-colonies of different species as shown in Figure 1(d) causes a change in electrochemical conditions within the biofilm as compared to that in the bulk environment. This change in electrochemistry of biofilm-metal system is characterized by a phenomenon called ennoblement, which displaces the corrosion potential to more positive potentials and increases the susceptibility of pitting. Some portions of biofilm slough away from the surface as shown in Figure 1(e), after which the exposed areas of the surface are recolonized by planktonic or sessile bacteria adjacent to the exposed areas as shown in Figure 1(f). As a result of biofilm formation, the concentration gradients of chemical species are formed across the thickness of biofilm, resulting in localized corrosion of the metal. Also, Figure 2 shows how the presence of SRB drags down the potential and favors pitting at lower potentials.

Investigating biocorrosion is not a new practice; instead a lot of work has already been done to develop an understanding of biofilm formation, mechanisms and microbes involved, and its prevention and control. 

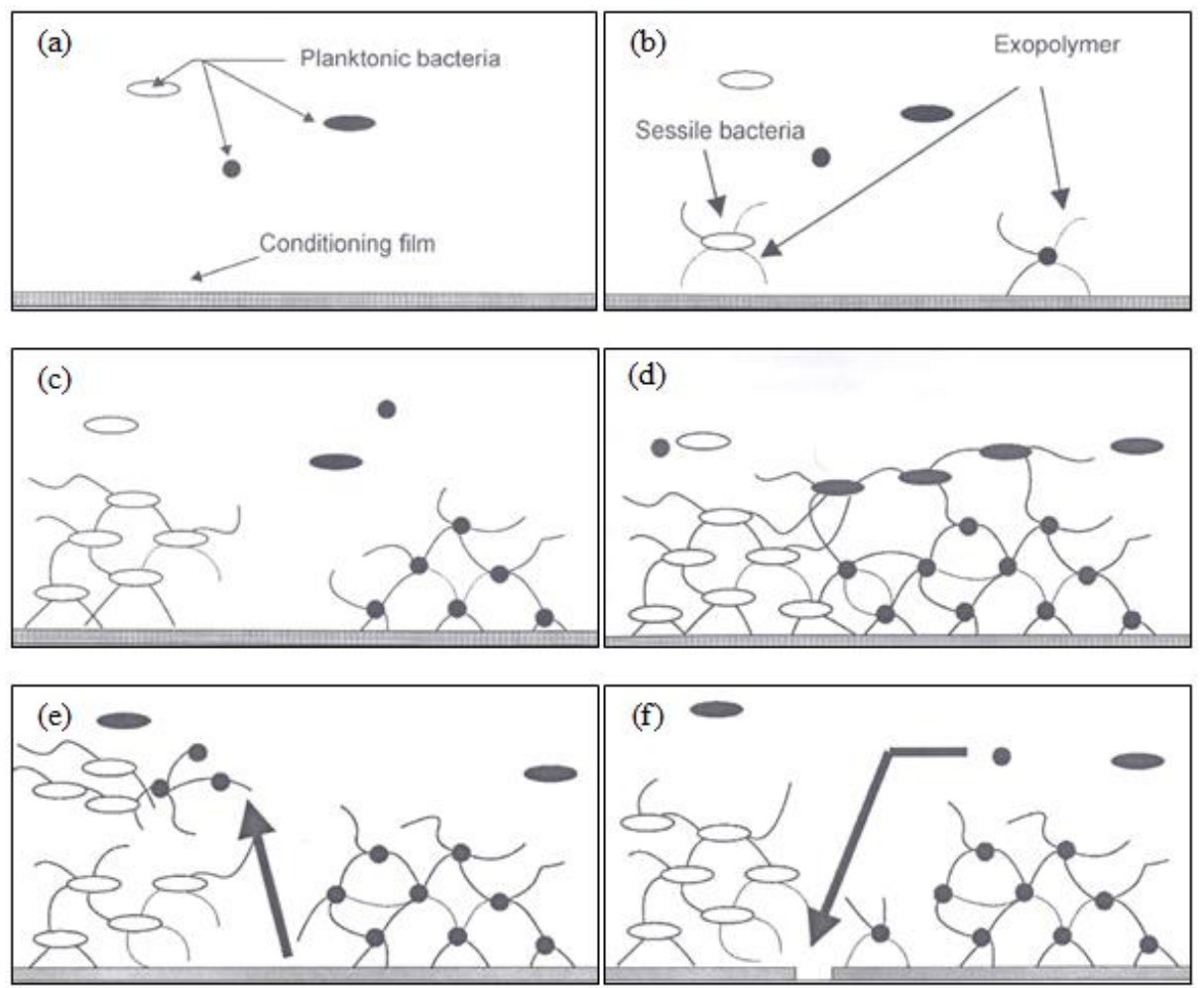

Figure 1. Stage wise development of biofilm [3].

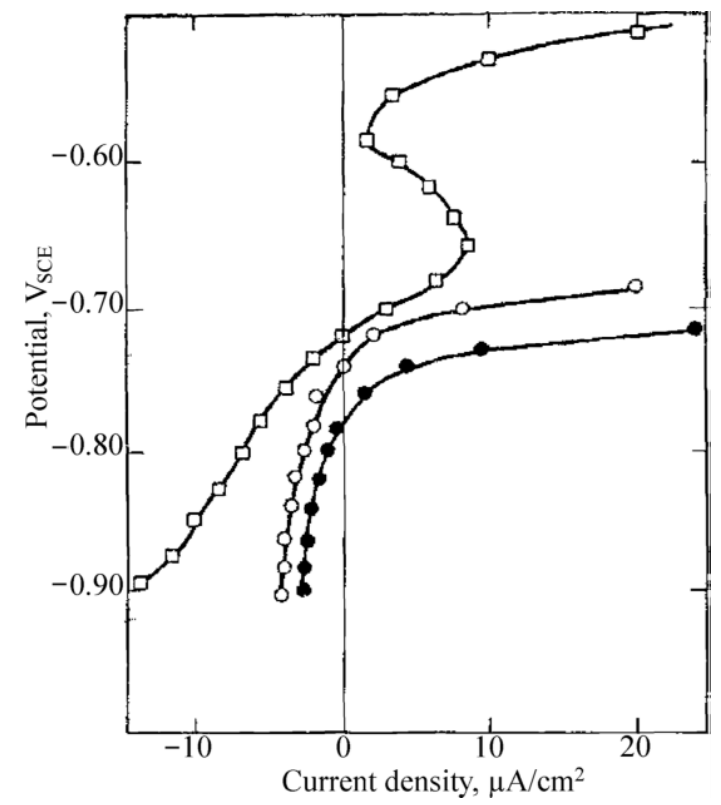

Figure 2. Effect of ennoblement on the susceptibility of pitting for AISI 1020 steel. Hollow squares correspond to results for anaerobic artificial seawater $(\mathrm{pH}=8.0)$. Hollow circles show the results for artificial seawater contaminated by $\mathrm{SRB}$ at $\mathrm{pH}=7.8$. Filled circles show the artificial seawater with addition of $\mathrm{Na}_{2} \mathrm{~S}$ at $\mathrm{pH}=8.0$ [7].

Muthukuma et al. [16] studied the degradation of oil due to bacteria which causes MIC and its prevention through corrosion inhibitors. It was emphasized that biocides or corrosion 
inhibitors should be carefully selected to make the most of applied biocide for MIC control. Al Abbas et al. [8] analyzed the thermodynamic and surface adhesion approach associated with bacterial adhesion. The study included a detailed investigation on the factors involved in bacterial adhesion with the metal surface, biofilm formation and its interaction with the substratum, followed by its role in biocorrosion in pipeline systems. A study on monitoring and control of microbial biofilms has been done by Maxwell et al. [10], where the essential requirements and available tools to monitor sessile bacteria are discussed. Efforts have been made to improve the efficacy of existing monitoring techniques for oilfield samples. This paper reviews the current understanding of MIC in oil and gas industry that has been developed through research activities over the recent past. A brief introduction of microorganisms involved in MIC is provided in Section 2. Section 3 reflects on different mechanisms of MIC. Monitoring and inspection methods for MIC problems are discussed in Section 4. Section 5 focuses on the controls and prevention methods for MIC problems particularly in oil and gas industries. Case studies are included in Section 6 of the paper to analyze how real time MIC problems are treated in the industry. Conclusions are summarized in the final section of the paper.

\section{Micro-organisms associated with MIC}

\subsection{Fungi}

Fungi associated with MIC can be classified into two types: filamentous forms (mould) and unicellular forms (yeasts) [6]. The filamentous forms enhance the corrosion by releasing organic acids as metabolites. Fungi being aerobic in nature are normally observed in aerobic habitats and are non-photosynthetic organisms. Fungi appear in both atmosphere and aqueous environment, and they increase the acidity by producing acetic, formic, oxalic and citric acid, which results in an accelerated corrosion.

\subsection{Bacteria}

Table 1. Classification of bacteria involved in MIC [3].

\begin{tabular}{|c|c|c|c|}
\hline Based on: & Shape and appearance & Temperature & Oxygen consumption \\
\hline & $\begin{array}{l}\text { Vibrio: comma-shaped } \\
\text { cells }\end{array}$ & $\begin{array}{l}\text { Mesophile: the bacteria } \\
\text { grows best at } 20-35^{\circ} \mathrm{C}\end{array}$ & $\begin{array}{l}\text { Strict or obligate anaerobes: do not } \\
\text { function in the presence of oxygen }\end{array}$ \\
\hline & $\begin{array}{l}\text { Bacillus: rod-shaped } \\
\text { cells }\end{array}$ & \multirow{4}{*}{$\begin{array}{l}\text { Thermophile: the } \\
\text { bacteria shows activity } \\
\text { above } 40^{\circ} \mathrm{C}\end{array}$} & $\begin{array}{l}\text { Aerobes: require oxygen in their } \\
\text { metabolism }\end{array}$ \\
\hline & $\begin{array}{l}\text { Coccus: round shaped } \\
\text { cells }\end{array}$ & & $\begin{array}{l}\text { Facultative anaerobes: can function } \\
\text { in the presence or absence of oxygen }\end{array}$ \\
\hline & \multirow[t]{2}{*}{$\begin{array}{l}\text { Myces for filamentous } \\
\text { fungi like cells } e t c \text {. }\end{array}$} & & $\begin{array}{l}\text { Micro-aerophiles: need low level of } \\
\text { oxygen }\end{array}$ \\
\hline & & & $\begin{array}{l}\text { Aero-tolemts: not affected by the } \\
\text { presence of oxygen }\end{array}$ \\
\hline
\end{tabular}


Bacteria involved in MIC can be categorized by their shape and appearance, temperature, and even by oxygen consumption. Various types of bacteria under these categories are presented in Table 1. These bacteria could be aerobic or anaerobic, however, anaerobic bacteria are considered to be the root cause of MIC in mediums such as moist soil and water. Previously, all MIC problems have been attributed to a well-known anaerobic bacteria i.e. Sulphate Reducing Bacteria (SRB). However, investigations on biocorrosion by many researchers provided a list of bacteria that can be involved in MIC, where SRB are just one of these groups [7, 17]. Some of these bacteria are discussed below.

\section{Sulphate reducing bacteria (SRB)}

The first and most popular microorganism in MIC is the sulphate reducing bacteria. They are anaerobic in nature, derive their energy from organic nutrients, grows in a $\mathrm{pH}$ range of 4.0-9.5 [18] and can withstand the pressures up to 500 atmospheres [7]. SRB reduce oxidized sulphur compounds, such as sulphate, sulphite and thiosulphate, as well as sulphur to $\mathrm{H}_{2} \mathrm{~S}$. Oil and gas industry is badly affected by the sulphides generated by these SRB. SRB can be found everywhere, from more than 70 meters deep in clay to seawater [19]. Various models have been proposed to demonstrate the mechanisms by which SRB corrodes a metal especially steel. Kuehr and Vlugt [20], in their cathodic depolarization theory, explained the oxidation of molecular hydrogen at cathode by an enzyme called hydrogenase. Increased hydrogen evolution directly accelerates the corrosion rate. Besides the cathodic depolarization theory, some other mechanism may include but not limited to anodic depolarization, production of corrosive iron sulphides, release of exopolymers capable of binding Fe-ions, sulphide-induced stress-corrosion cracking etc. [17]. The reaction equation for SRB is:

$$
\begin{gathered}
\mathrm{SO}_{4}^{2-}+\mathrm{CH}_{3} \mathrm{COOH}+2 \mathrm{H}^{+} \rightarrow \mathrm{HS}^{-}+2 \mathrm{HCO}_{3}^{-}+3 \mathrm{H}^{+} \\
\mathrm{HS}^{-}+\mathrm{Me}^{2+} \rightarrow \mathrm{MeS}+\mathrm{H}^{+}
\end{gathered}
$$

$\mathrm{Me}^{2+}$ can be for example copper, zinc etc.

Sulphate/sulphide oxidizing bacteria (SOB)

Sulphate oxidizing bacteria (SOB) are aerobic in nature which means they need oxygen for their metabolism. SOB grows at low $\mathrm{pH}$ values and in environments like solids, soils, and water that contains sulphide minerals. SOB produces sulphuric acid from sulphur or sulfide. Both SOB and SRB can co-exist in the system. Since the reaction mechanism of SOB is complex and involves many intermediate products, the reader is referred to the article by Friedrich et al. [21] for better understanding of this mechanism. 


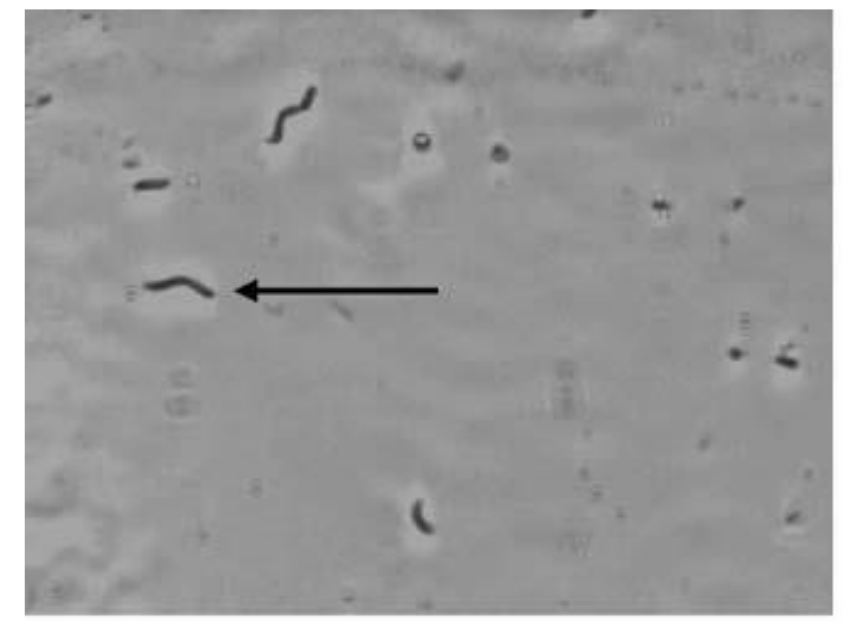

a

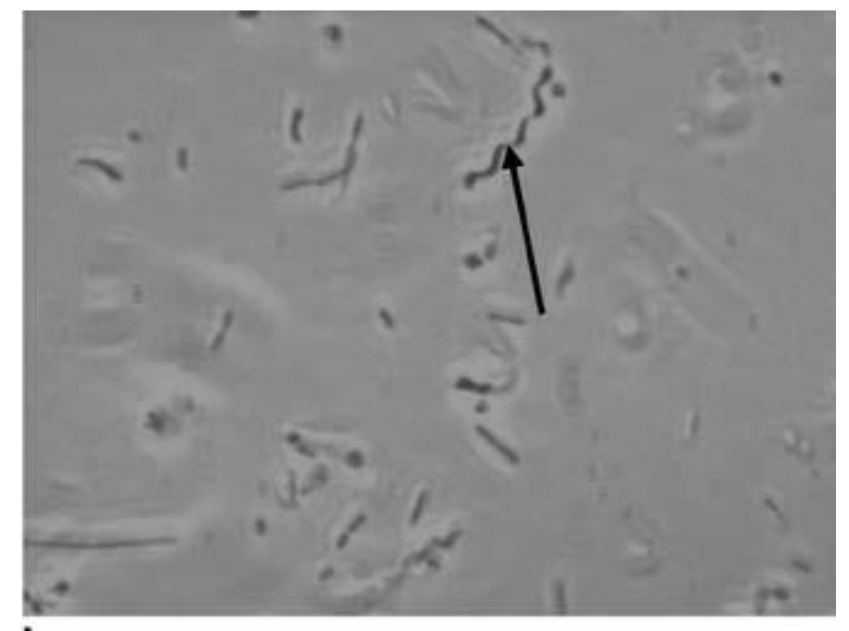

b

Figure 3. Morphology of SRB (a) vibrio, (b) spiral [7].

\section{Metal reducing bacteria (MRB)}

Metal reducing bacteria (MRB) could be aerobic, anaerobic or facultative aerobic in nature. These MRB reduce insoluble ferric compounds to soluble ferrous ions. Due to insoluble nature of ferric ions, ferric salts assist in corrosion control by chemical activity. Unlike ferric salts, ferrous salts are mostly soluble which results in the removal of protective layer [16]. Hence, metal reducing bacteria or simply iron reducing bacteria directly promote corrosion in the system. For detailed reaction mechanism of microbial reduction of different metals, the readers are referred to the article by Lloyd [22].

\section{Metal oxidizing bacteria (MOB)}

Metal oxidizing bacteria or commonly known as iron oxidizing bacteria reduces ferrous ions to ferric ions [16]. These bacteria are aerobic in nature, particularly microaerophiles which requires low level of oxygen for their metabolism. Bacteria of these genera can also oxidize manganous ions to manganic ions with associated deposition of manganese dioxide. The accumulation of metal oxidizing bacteria on metal surfaces promotes corrosion by deposition of cathodically reactive ferric and manganic oxides and the local consumption of oxygen caused by bacterial respiration in the deposit [17]. The reaction equation for oxidation of iron in the presence of bacteria like Thiobacillus ferrooxidans, Leptospirillum ferrooxidans and Sulfolobus acidocaldarius which are able to oxidize ferrous iron is [23]:

$$
2 \mathrm{Fe}^{2+}+0.5 \mathrm{O}_{2}+2 \mathrm{H}^{+} \rightarrow 2 \mathrm{Fe}^{3+}+\mathrm{H}_{2} \mathrm{O}
$$

\section{Acid producing bacteria (APB)}

Bacteria are capable of producing good amounts of organic and inorganic acids such as nitric acid $\left(\mathrm{HNO}_{3}\right)$, sulphurous acid $\left(\mathrm{H}_{2} \mathrm{SO}_{3}\right)$, sulphuric acid $\left(\mathrm{H}_{2} \mathrm{SO}_{4}\right)$, nitrous acid $\left(\mathrm{HNO}_{2}\right)$, and carbonic acid $\left(\mathrm{H}_{2} \mathrm{CO}_{3}\right)$ [17]. Corrosion resulting from nitric and sulphuric acid produces water soluble salts which cannot provide a protective layer against MIC. Moreover, the protecting deposits on the surface are expected to dissolve due to lower $\mathrm{pH}$ of the system. 
Other problems may arise due to high concentrations of carbonic acid, which can react with calcium hydroxide and produce the insoluble calcium carbonate $\left(\mathrm{CaCO}_{3}\right)$ and aggressive carbonic acid i.e. water soluble calcium hydrogen carbonate $\left(\mathrm{Ca}\left(\mathrm{HCO}_{3}\right)_{2}\right)$.

A detailed description of different species in bacteria and fungi is provided in Ref. [24] including the $\mathrm{pH}$ and temperature ranges, oxygen requirements, the metals affected and the metabolic process of these species. Therefore, reader is referred to the mentioned reference for better understanding.

\section{Mechanisms of microbiologically influenced corrosion}

The complex nature of microbiologically influenced corrosion needs an in-depth understanding of the mechanisms involved in metal degradation by microbial activity. A number of theories and models have been presented, explaining how MIC progresses in the systems. Some of these mechanisms are included in this study.

Cathodic depolarization theory (Kuehr and Vlugt, 1934 [20])

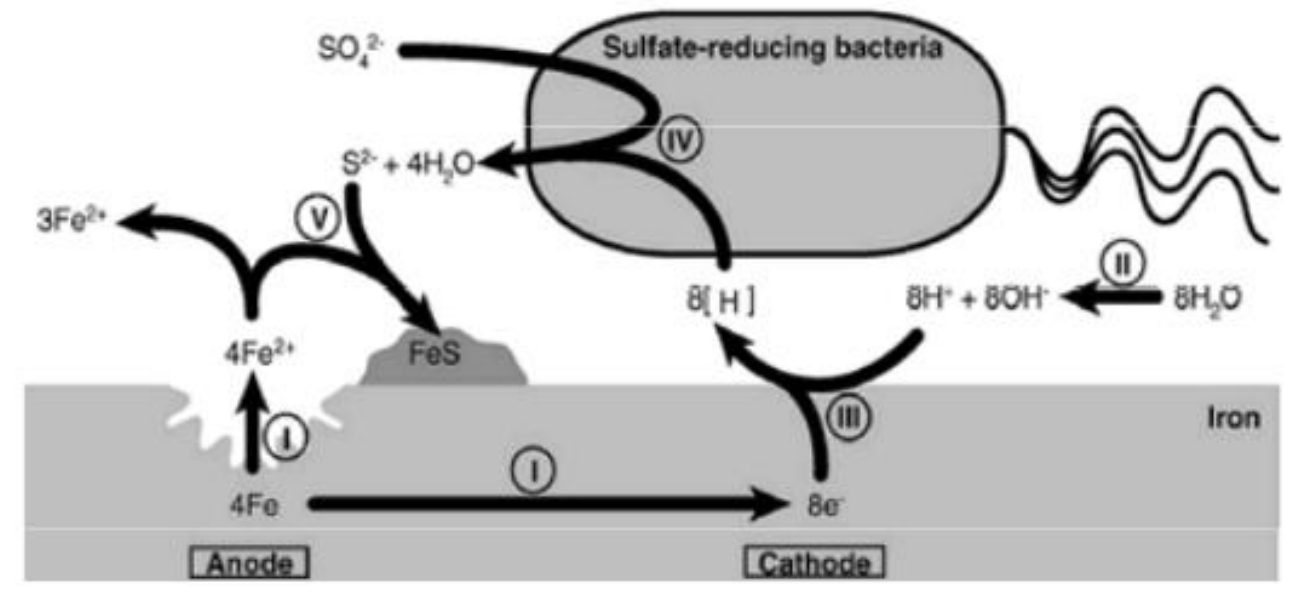

Figure 4. Schematic diagram of MIC by SRB in accordance with cathodic depolarization theory [26].

Cathodic depolarization theory demonstrates the corrosion derived by SRB through the oxidation of cathodic hydrogen by an enzyme called hydrogenase. During any corrosion problem, metal undergoes dissolution into its anions, whereas reduction of hydrogen takes place at cathode to maintain a dynamic equilibrium in the system. SRB consumes the cathodic hydrogen as explained by reaction (4) in Table 2, and oxidizes the Fe [25-27]. Consequently, it expedites the dissolution of metal at anode together with the formation of corrosion products such as $\mathrm{FeS}$ and $\mathrm{Fe}(\mathrm{OH})_{2}$ [28]. A description of iron corrosion due to $\mathrm{SRB}$ is presented in Figure 4. In the presence of $\mathrm{CO}$ and bicarbonate, as common in marine environments, the remaining $\mathrm{Fe}^{2+}$ precipitates as $\mathrm{FeCO}_{3}$ in the absence of bicarbonate, the more soluble $\mathrm{Fe}(\mathrm{OH})_{2}$ is formed [29, 30]. 
Table 2. Reaction for cathodic depolarization mechanism of MIC by SRB [9].

\begin{tabular}{ll}
\hline Anodic reaction (1) & $4 \mathrm{Fe} \rightarrow 4 \mathrm{Fe}^{2+}+8 \mathrm{e}^{-}$ \\
Water dissociation (2) & $8 \mathrm{H}_{2} \mathrm{O} \rightarrow 8 \mathrm{H}^{+}+8 \mathrm{OH}^{-}$ \\
Cathodic reaction (3) & $8 \mathrm{H}^{+}+8 \mathrm{e}^{-} \rightarrow 8 \mathrm{H}+4 \mathrm{H}_{2}$ \\
Hydrogen oxidation (4) & $\mathrm{SO}_{4}^{2-}+4 \mathrm{H}_{2} \rightarrow \mathrm{H}_{2} \mathrm{~S}+2 \mathrm{H}_{2} \mathrm{O}+2 \mathrm{OH}^{-}$ \\
Precipitation (5) & $\mathrm{Fe}^{2+}+\mathrm{S}^{2-} \rightarrow \mathrm{FeS}$ \\
Precipitation (6) & $3 \mathrm{Fe}^{2+}+6 \mathrm{OH}^{-} \rightarrow 3 \mathrm{Fe}(\mathrm{OH})_{2}$ \\
Total reaction (7) & $4 \mathrm{Fe}+\mathrm{SO}_{4}^{2-}+4 \mathrm{H}_{2} \mathrm{O} \rightarrow \mathrm{FeS}+3 \mathrm{Fe}(\mathrm{OH})_{2}+2 \mathrm{OH}^{-}$
\end{tabular}

Iron sulphide mechanism (King and Miller, 1971) [31]

Kings and Miller [31] put forwarded the idea of formation FeS in the system and explained the activity through galvanic effect. According to this mechanism, a sufficient amount of FeS is formed into the system, followed by which the area covered with FeS starts to act like cathode whereas the biofilm area starts to act like anode [28]. Higher concentration of $\mathrm{Fe}^{2+}$ ions in the system causes a crack in the protective Mackinawite film, and results in an accelerated corrosion [32-34]. Figure 5 depicts the corrosion mechanism through galvanic effect as proposed by King and Miller. Lee and Characklis [35] studied the impact of suspended FeS on the corrosion of mild steel in an anaerobic biofilm reactor where the $\mathrm{Fe}^{2+}$ concentration rose from 0 to $60 \mathrm{mg} / \mathrm{L}$. When the increase of $\mathrm{Fe}^{2+}$ concentration reached $60 \mathrm{mg} / \mathrm{L}, \mathrm{FeS}$ particles were able to penetrate through the protective iron sulfide film, consequently the protective film was ruptured. Intergranular corrosion were also detected on the metal surface by SEM imaging.

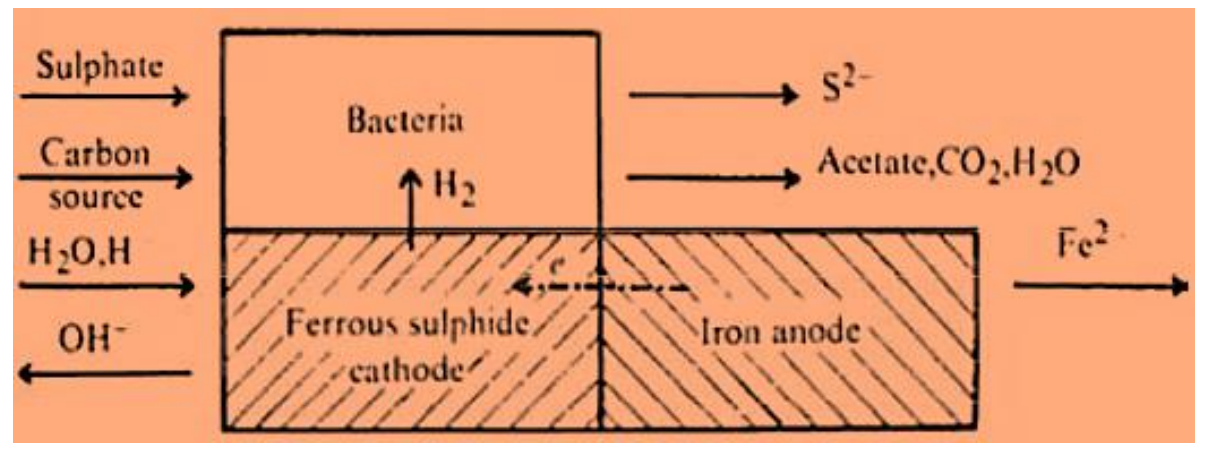

Figure 5. King's mechanism of MIC by SRB [34].

Volatile phosphorus compound (Iverson and Oslon, 1983 [36])

A new idea of biocorrosion was proposed by Iverson and Olson [36, 37] where it was assumed that SRB accelerates the corrosion reaction through the formation of corrosion products such as phosphine $\left(\mathrm{H}_{3} \mathrm{P}\right)$, followed by the formation of iron phosphide $\left(\mathrm{FE}_{2} \mathrm{P}\right)$ [28]. 
It was reported that phosphorus compounds were observed in yeast extract, which might be an originator to the corrosive phosphorus compounds.

Anodic depolarization (1984) [38]

Anodic depolarization was also studied as being a mechanism of MIC in metals [38]. The electrochemical reactions for iron dissolution to $\mathrm{Fe}^{2+}$, water dissociation to $\mathrm{H}^{+}$, and formation of a protective layer of $\mathrm{H}_{2}$ gas remains same as in cathodic depolarization theory as shown in Table 4. However, anodic depolarization as shown in reaction (4) of Table 3 forms the corrosion product $\mathrm{FE}(\mathrm{OH})_{2}$ [39]. SRB reduces $\mathrm{SO}_{4}^{2-}$ to $\mathrm{H}_{2} \mathrm{~S}$ as in reaction (5), followed by which further dissolution of $\mathrm{H}_{2} \mathrm{~S}$ directly influences the $\mathrm{H}^{+}$concentration in the system. With the increased concentration of $\mathrm{H}^{+}$ions, the corrosion rate is expected to be increased. Also, the $\mathrm{S}^{2-}$ ions from reaction (6) and $\mathrm{Fe}^{2+}$ ions react to form another corrosion product $\mathrm{FeS}$ through anodic polarization as in reaction (7) [40-42]. Wang and Liang demonstrated that SRB accelerates anodic active dissolution of 10CrMoAl steel in seawater through anodic depolarization process of sulfide. The $\mathrm{S}^{2-}$ ions from SRB activity reacts with $\mathrm{Fe}^{2+}$ ions to form FeS that will accelerate anodic active dissolution [43].

Table 3. Reaction for anodic depolarization mechanism of MIC by SRB [7].

\begin{tabular}{ll}
\hline Anodic reaction & $4 \mathrm{Fe} \rightarrow 4 \mathrm{Fe}^{2+}+8 \mathrm{e}^{-}$ \\
Water dissociation & $8 \mathrm{H}_{2} \mathrm{O} \rightarrow 8 \mathrm{H}^{+}+8 \mathrm{OH}^{-}$ \\
Cathodic reaction & $8 \mathrm{H}^{+}+8 \mathrm{e}^{-} \rightarrow 8 \mathrm{H}+4 \mathrm{H}_{2}$ \\
Anodic polarization & $3 \mathrm{Fe}^{2+}+6 \mathrm{OH}^{-} \rightarrow 3 \mathrm{Fe}(\mathrm{OH})_{2}$ \\
Hydrogen oxidation & $\mathrm{SO}_{4}^{2-}+4 \mathrm{H}_{2} \rightarrow \mathrm{H}_{2} \mathrm{~S}+2 \mathrm{H}_{2} \mathrm{O}+2 \mathrm{OH}^{-}$ \\
Dissociation of hydrogen sulfide & $\mathrm{H}_{2} \mathrm{~S} \rightarrow \mathrm{S}^{2-}+2 \mathrm{H}^{+}$ \\
Anodic polarization & $\mathrm{Fe}^{2+}+\mathrm{S}^{2-} \rightarrow \mathrm{FeS}$ \\
Total reaction & $4 \mathrm{Fe}+\mathrm{SO}_{4}^{2-}+4 \mathrm{H}_{2} \mathrm{O} \rightarrow \mathrm{FeS}+3 \mathrm{Fe}(\mathrm{OH})_{2}+2 \mathrm{OH}^{-}$ \\
\hline
\end{tabular}

\section{Metal-binding exopolymers (1995) [44]}

Biofilms consists of microorganisms and extracellular polymeric substances (EPS). EPS produces by sulphate reducing bacteria are capable of binding with metal ions to expedite corrosion [44-46]. Various studies on this binding property of EPS provided evidence of accelerated corrosion. Fang et al. [47] reported high corrosion rate of mild steel in seawater due to binding of EPS with $\mathrm{CR}^{3+}$ ions. Chan et al. [48] declared EPS as a self-corroding agent by conducting an experiment without EPS and with 1\% EPS where the later shows an accelerated corrosion.

Videla [49] presented four steps for biofilm formation on the metal surface as following: 
1. Transportation of organic material to metal surface

2. Transportation of microbial cells from bulk to surface

3. Attachment of microbial cells

4. Growth within the biofilm.

Biomineralization (Little, 1998) [50]

Biomineralization is a phenomenon where microorganisms form minerals. The effect of biomineralization was demonstrated by Little et al. [50] in two different ways. First was the biomineral dissolution caused by metal reducing bacteria which remove protective oxide layers, and the other was forced mineral replacement which stimulates metal decomposition. Based on the nature of mineral formed during metal deposition, the corrosion potential and thus the corrosion rate can accelerate or decelerate. However, precipitation of sulphides due to biomineralization results in a more negative (active) corrosion potential suggesting an enhanced corrosion rate.

Romero Mechanism (Romero, 2005) [51]

A three stage mechanism of MIC was proposed by Romero [51] as shown in Figure 6. In the first stage, biofilm formation takes place by the adsorption of bacteria and FeS products. Galvanic effect is also observed during this stage owing to the different electrochemical nature of metal surface and FeS products. Followed by this, the biofilm develops and stabilize, and metal experiences ennoblement which drives its potential to more positive so that it becomes susceptible to pitting. Finally, SRB activity reduces the $\mathrm{pH}$ of the system in the presence of $\mathrm{HS}^{-}$, leading to an intense localized corrosion attack by galvanic effect between the anodic metal and the cathodic FeS products [52]. The stage wise electrochemical reactions of Romero mechanism are presented in Table 4.

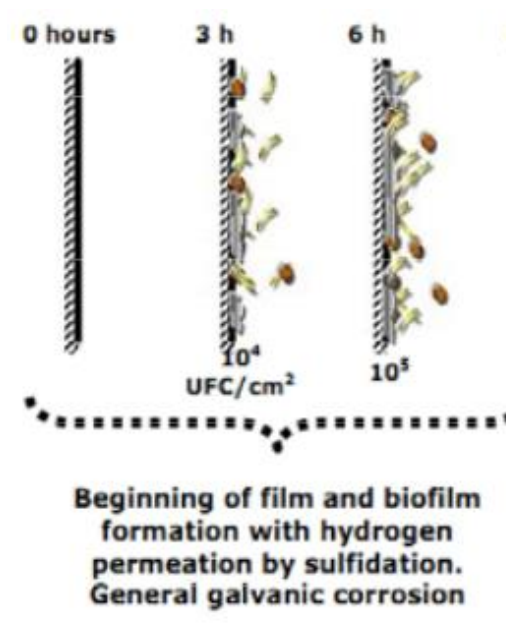

Stage I

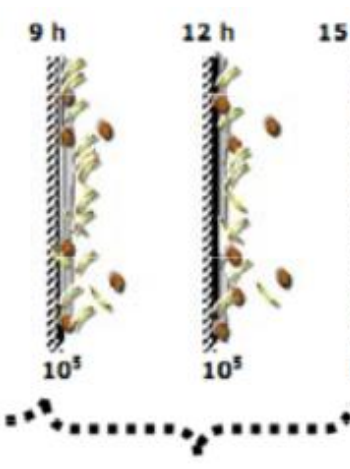

Film and biofilm stabilization and ennoblement of material.

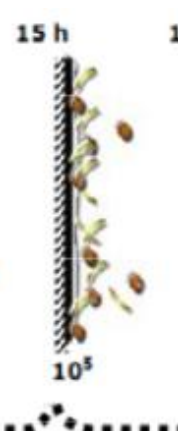

$18 \mathrm{~h}$

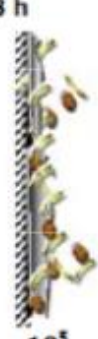

Detachment of film and biofilm. Localized galvanic corrosion

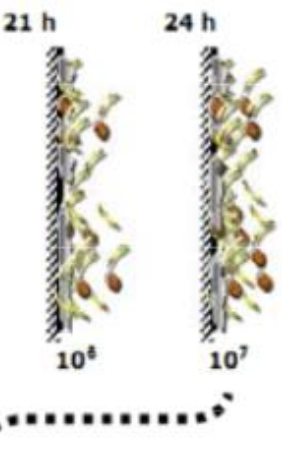

Stage III

Figure 6. Romero three stage mechanism of MIC [51]. 
Table 4. Reaction for Romero three stage mechanisms of MIC [7].

The first stage reactions of Romero mechanism (3-9 h)

$\begin{array}{lr}\mathrm{H}_{2} \mathrm{~S} \rightarrow \mathrm{HS}+\mathrm{H}^{+} & 1 \\ \mathrm{Fe}^{++}+\mathrm{HS} \rightarrow \mathrm{FeS}+\mathrm{H}^{+} & 2 \\ \mathrm{FeS}+\mathrm{HS} \rightarrow \mathrm{FeS}_{2}+\mathrm{H}^{+}+2 \mathrm{e}^{-} & 3 \\ 3 \mathrm{FeS}+\mathrm{HS} \rightarrow \mathrm{Fe}_{3} \mathrm{~S}_{4}+\mathrm{H}^{+}+2 \mathrm{e}^{-} & 4 \\ 2 \mathrm{H}^{+}+2 \mathrm{e}^{-} \rightarrow \mathrm{H}_{2} & \\ \mathrm{Fe} \rightarrow \mathrm{Fe}^{++}+2 \mathrm{e}^{-} & 5 \\ \mathrm{Fe}+\mathrm{HS} \rightarrow \mathrm{FeS}+\mathrm{H}^{+}+2 \mathrm{e}^{-} & \text {galvanic }\end{array}$

The second stage reactions of Romero mechanism (9-15 h)

$\mathrm{FeS}_{2}(\mathrm{C}) \rightarrow \mathrm{FeS}_{2}(\mathrm{O})$

$\mathrm{Fe}_{3} \mathrm{~S}_{4}(\mathrm{R}) \rightarrow \mathrm{Fe}_{3} \mathrm{~S}_{4}(\mathrm{C})$

$\mathrm{Fe}+\mathrm{HS}^{-} \rightarrow \mathrm{FeS}+\mathrm{H}^{+}+2 \mathrm{e}^{-}$

microbial

$2 \mathrm{H}^{+}+2 \mathrm{e}^{-} \rightarrow \mathrm{H}_{2}$

The third stage reactions of Romero mechanism (>15 h)

\begin{tabular}{|c|c|c|}
\hline $\mathrm{FeS}_{2}+\mathrm{H}^{+}+2 \mathrm{e}^{-} \rightarrow \mathrm{FeS}+\mathrm{HS}^{-}$ & & 1 \\
\hline $\mathrm{Fe} \rightarrow \mathrm{Fe}^{++}+2 \mathrm{e}^{-}$ & galvanic & 2 \\
\hline $\mathrm{FeS}+\mathrm{HS} \rightarrow \mathrm{FeS}+\mathrm{H}^{+}+2 \mathrm{e}^{-}$ & microbial & 3 \\
\hline $\mathrm{H}_{2} \mathrm{~S}+\mathrm{e}^{-} \rightarrow 0.5 \mathrm{H}_{2}$ & & 4 \\
\hline $7 \mathrm{FeS}+\mathrm{HS}^{-} \rightarrow \mathrm{Fe}_{7} \mathrm{~S}_{8}+\mathrm{H}^{+}+2 \mathrm{e}^{-}$ & & 5 \\
\hline
\end{tabular}

Biocatalytic cathodic sulphate reduction (2009) [53]

Biocatalytic cathodic sulphate reduction (BCSR) theory states that reduction of sulphate ions at cathode consumes the cations produced during the anodic reaction with the aid of biocatalyst and the metal-biofilm interface can act like both the anodic and cathodic sites. Following electrochemical reactions are assumed to take place during the formation of a corrosive SRB biofilm on iron surface in the presence of biocatalyst.

Anodic: $4 \mathrm{Fe} \rightarrow 4 \mathrm{Fe}^{2+}+8 \mathrm{e}^{-}$

Cathodic: $\mathrm{SO}_{4}^{2-}+8 \mathrm{H}^{+}+8 \mathrm{e}^{-} \rightarrow \mathrm{HS}^{-}+\mathrm{OH}^{-}+3 \mathrm{H}_{2} \mathrm{O}$ 


\section{Characterization, monitoring and inspection of MIC}

Characterization, monitoring and inspection of MIC are essential in order to prevent, control, or even mitigate these occurrences. With good characterization, monitoring and inspection systems, equipment failure and extensive maintenance can be avoided, especially in oil and gas industries with extraordinary downtime costs. Identification of MIC has been found a tricky exercise due to the fact that the process results in more or less similar failures as in other forms of corrosion. However, with knowledge and experience in the field, it is now possible to identify which systems are more vulnerable to MIC and to analyze the pit morphology, appearance and colors of corrosion products responsible for MIC. For example, black colored, smelly FeS corrosion products results from sulphate reducing bacteria. Also, reddish-brown colored deposits are representative of iron-oxidizing bacteria in the system [7]. The details of characterization, monitoring and inspection methods for biocorrosion are as follows.

\subsection{Characterization of MIC}

\subsubsection{Bacteria culture}

For MIC scenarios, understanding the mechanism of biofilm formation and microbe's population is of prime interest and it can be done via "Bacteria Culture". Bacteria culture refers to the growth of bacterial species in a created environment provided with the nutrients and temperature required for this growth. Although the method is good for identification of bacterial species responsible for biofilm formation, it is unreliable at times when some species grow and the others not due to limitations in creating the culture environment. One such example is reported by Little et al where SRB and oil oxidizing bacteria coexist in a system, the culture showed discrepancies between the actual and observed corrosion rate of mild steel [54].

\subsubsection{Molecular biology methods}

Unlike culture, molecular biology methods are based on utilizing the genetic material of bacteria i.e. DNA and RNA. Identification of bacteria associated with MIC become possible with these methods. Also, these methods indicate whether bacteria are influenced by the biocides or are resistant to biocides.

\subsubsection{Microscopic examination}

Microscopic methods have always been an effective method of quantifying the bacteria in MIC problems using staining/counting techniques. Large and unique bacteria such as filamentous iron bacteria and stalked iron oxidizer can be observed directly under microscope [7]. However, microscopic examination is not capable of identifying individual bacterial families which looks similar to each other, therefore it might overlook some important bacteria that are actively participating in MIC problems. Other microscopic examinations includes scanning electron microscopy (SEM), transmission electron 
microcopy (TEM), environmental scanning and transmission electron microscopy (ESEM) and (ETEM), which provides insights on biofilm composition and development in a more detailed manner compared to normal microscopic examination.

\subsubsection{Electrochemical methods}

Several electrochemical methods are available for characterizing MIC problems such as weight loss method (using test coupons), electrical resistance method, polarization resistance method, and potentiodynamic sweep techniques etc. However, Gilbert and Herbert et al. reported that these methods are effective neither in identifying the type nor in quantifying the number of organisms causing biodetorioration of a system [55]. This might be due to the fact that these methods are designed to monitor uniform corrosion, which usually is not the case in MIC where the corrosion attack is mostly localized. Nevertheless, beyond its standalone state, linear polarization coupled with other electrochemical methods can be used to obtain valuable data about biodetorioration in a system. Also, another technique i.e. Electrochemical impedance spectroscopy (EIS) is widely used for analysis of sulphide films formed on steel during MIC. The readers are referred to the recent review paper on EIS by Kashkovskiy et al. [56] to get more practical information about the EIS.

\subsubsection{Quick check tests}

Quick check test methods only determine the presence of MIC and associated bacteria in the system. The results of any quick check method could be just "Yes" or "No" for (I) an MIC occurrence and/or (II) the availability of microorganisms that can cause MIC. Some of the quick check test methods are hydrogenase test, antibody tests and fatty acid analyses.

\subsection{Monitoring and inspection}

It is of utmost importance to monitor or inspect only equipment which is most vulnerable to MIC in oil and gas industry. Certainly the equipment within an oil and gas processing and transportation facility can be prioritized such as pipeline systems, where there is a high probability of corrosive products such as FeS, are more prone to MIC and thus needs frequent monitoring and inspection.

\subsubsection{Sampling devices}

Oil and gas production and transportation facilities undergo severe consequences of MIC, and thus it necessitates sampling for a detailed investigation of microbial activity taking place within the system. Videla et al. [55] categorized these sampling devices as "directly implanted in the system" and "side-stream devices". Directly implanted sampling devices either fit into the pipe wall or they are integrated with the fittings already exist in the piping system. Test coupons are prepared with the same material to the one which needs to be tested, however, an identical material with similar properties can also be used. Drawing of these test coupons from the system after a certain immersion/exposure period is done with great 
care to avoid any direct contact between the biofilm formed on test coupons and the drawing tools.

Side-stream devices work in parallel to the main system under same operating conditions. It is important that side-stream environment must be capable of replicating the biocorrosion as in mainstream at least on a qualitative basis. Although directly implanted sampling provides an exact description of the microbial activity with the system, the sidestream sampling offers more flexibility in terms of post sampling inspection and testing procedures.

\subsubsection{Laboratory rigs}

Laboratory rigs are another way of investigating the details of MIC problem such as mechanism of biofilm formation, family of microbes involved in a particular MIC occurrence, rate of biofilm development etc. Sampling devices as described in section 4.1 are used in these laboratory rigs containing actual or simulated process fluid. Use of laboratory rigs allows more sophisticated instrumentation and methods to understand MIC problems, yet they sometimes pose challenges in terms of inconsistencies between the real and lab environment. "Feed and Bleed" type laboratory rigs are extensively used as proposed by King et al., where the liquid within the rig is circulated with uninterrupted addition and removal of the fresh medium (feed) and spent medium (bleed) respectively [55].

\subsubsection{Online monitoring techniques}

Direct online monitoring of MIC problems could be very useful in real time biofilm monitoring in MIC problems. One such technique was reported by Stokes et al., where three different electrochemical methods were combined to develop a monitoring sensor capable of providing corrosion information [57]. These three electrochemical methods are zero resistance ammetry (ZRA), electrochemical current noise $(\mathrm{ECN})$, and linear polarization resistance (LPRM) [55]. A continuous monitoring of corrosion at metal-biofilm interface is possible using the device, and prevention and control methods can be devised based on the collected information. Localized corrosion monitor (LCM) by Enzien and Yang [13] and Electrochemical Probes by Licina et al. [58] are some other developments in online monitoring of MIC. Real time data acquisition is possible in these techniques due to the integration of hardware and software and thus a biofilm causing MIC activity can be accurately monitored online.

\section{Prevention and control of MIC}

MIC can be prevented and controlled in a number of ways, some of which are explained in the following sub-sections.

\subsection{Cleaning methods}

MIC derived from deposits on metal surface, such as scaling and sediments, can be reduced through cleaning methods. Chemical composition, $\mathrm{pH}$, temperature, and operating 
conditions of the flow stream influences the type of scaling whereas, sedimentation is primarily caused by suspended matter which sticks to the metal surface. These scales and sediments along with water, when attached to metal surface, provide an ideal environment for bacterial growth and initiation of MIC. Therefore, an appropriate cleaning method is always needed in oil and gas production and transportation facilities to avoid MIC caused by scaling and sedimentation. However, a number of factors have to be taken into account for selection of cleaning method such as material to be cleaned, geometry (accessible area), type of joints (flanged or welded) etc. Table 5 lists the basic selection criteria for selection of cleaning method.

Table 5. Selection of cleaning method [7].

1. Identification of material to be removed

2. Determination of material surface to be cleaned

3. Evaluation of condition of the surface to be cleaned

4. The extent of cleaning required

5. Limitations due to geometry of the structure or system components

6. Environmental impact

7. Cost

Cleaning methods are classified into I. Mechanical cleaning and II. Chemical cleaning. Each of these classifications is discussed below.

\subsubsection{Mechanical cleaning}

The physical removal of deposits from metal surface is defined as mechanical cleaning. Various tools can be used to perform mechanical cleaning such as brushes, pigs, cleaning sphere and/or high velocity water jets in some cases. Oil and gas pipelines experiencing scaling, sedimentation and encrustations are normally treated with mechanical pigs, however, brushes, sand papers, chisels and other methods such as sand and grit blasting may also be used if required. Pipelines and other systems cleaned mechanically may suffer from scaling and sludge leftovers which might cause pitting and corrosion due to creation of differential concentration cells. Hence, it is important to use a biocide together with mechanical means to ensure a complete cleanup of the system.

\subsubsection{Chemical cleaning}

Followed by mechanical cleaning, systems are usually treated by chemicals to cover the areas which are not accessible by mechanical means. Three types of chemicals are mostly used: Mineral Acids such as $\mathrm{HCl}$ and $\mathrm{H}_{2} \mathrm{SO}_{4}$ together with corrosion inhibitors to give protection against the acid attack on metal, Organic acids such as acetic acid, formic acid, citric acid etc. for the systems which are not compatible with corrosion inhibitors and requires continuous cleaning. Chelating agents capable of forming complexes with metal cations, are used to remove copper and/or iron oxides but cannot remove the scaling caused 
by carbonates and phosphates [55]. Table 6 summarizes some chemical agents for cleaning different types of deposits.

Table 6. Chemical agent selection based on type of inorganic deposit [7].

\begin{tabular}{cccccc}
\hline \multirow{2}{*}{ Chemical agent } & \multicolumn{5}{c}{ Type of inorganic deposit } \\
\cline { 2 - 6 } & Carbonate & Phosphates & Sulfides & Iron oxides & Copper oxides \\
\hline Sulfuric acid & No & No & No & Yes & No \\
Citric acid & No & No & No & Yes & No \\
Hydrochloric acid & Yes & Yes & Yes & Yes & Yes \\
Sulfamic acid & Yes & No & No & No & No \\
Phosphoric acid & Yes & No & No & Yes & No \\
Formic acid & Yes & Yes & No & Yes & No \\
EDTA & Yes & Yes & No & No & No \\
\hline
\end{tabular}

\subsection{Biocides}

Biocides are the most common method for preventing and controlling MIC problems. By definition, biocides are compounds (or a combination of compounds) which can eradicate microorganisms and inhibit microbial growth. In general, biocides are required to behave bactericidal, algicidal and fungicidal for disinfecting any system, however, such broadspectrum compounds are not easily available. Therefore, in a practical application of biocide, the microorganism to be killed and operating conditions plays an important role in deciding the type of biocide and their appropriate dosage. Typical properties of a biocide are listed in Table 7. Biocides are classified into (I) Oxidizing Biocides (II) Non-oxidizing Biocides, the details of which are provided in the following subsections.

Table 7. Typical properties of a biocide [7].

1. Selectivity against target microorganisms

2. Capability to maintain its inhibitory effect in the presence of other compounds and under operating conditions of the system

3. Lack of corrosivity

4. Biodegradability

5. Low cost

\subsubsection{Oxidizing biocides}

Four main oxidizing biocides extensively used in industrial applications are Chlorine, Bromine, Ozone and Hydrogen Peroxide. 


\section{Chlorine}

Chlorine is one the mostly used bactericide and algaecide in MIC problems. The hydrolysis of chlorine results in hydrochloric $(\mathrm{HCl})$ and hypochlorous $(\mathrm{HOCl})$ acids. $\mathrm{HOCl}$ acts as a biocide but it is highly dependent on $\mathrm{pH}$. It was reported that $\mathrm{HOCl}$ acts best in a $\mathrm{pH}$ range of $6.5-7.5$ [11]. $0.1-0.2 \mathrm{mg} / 1$ are considered to be appropriate dosage for continuous treatment, whereas for intermittent treatment these values lie between $0.5-1 \mathrm{mg} / \mathrm{l}$ [55]. Apart from using it in gaseous form, it can also be derived from hypochlorous salts such as calcium hypochlorite $\left(\mathrm{Ca}(\mathrm{OCl})_{2}\right)$ and sodium hypochlorite $(\mathrm{NaOCl})$. Another compound which is used instead of gaseous chlorine is chlorine dioxide $\left(\mathrm{ClO}_{2}\right)$, which is more cost effective as a lesser amount of $\mathrm{ClO}_{2}$ is required, as compared to gaseous chlorine, to treat a similar problem.

\section{Bromine}

Similar to hypochlorous acid, bromine forms hypobromous acid ( $\mathrm{HOBr}$ ) which serves as biocide. $\mathrm{HOBr}$ is stable over a larger $\mathrm{pH}$ range than $\mathrm{HOCl}$. With a lower volatility, the biocidal action of bromine is longer as compared to chlorine. Mostly bromine is introduced to MIC problems using solid brominated hydantoins such as bromo-chloro-dimethylhydantoin (BCDMH) and bromo-chloro-ethylmethyl-hydantoin (BCEMH), lower concentrations of which are found effective in controlling planktonic bacteria efficiently [Kramer 2001]. In terms of biocidal effect and biofilm removal, BCDMH is considered to be more efficient than BCEMH.

\section{Ozone}

Ozone has gained popularity as a biocide due to a number of advantages, such as it is highly oxidative and works well against many bacterial species and microbial biofilms, minimum or no residuals as it is produced and consumed simultaneously, and it do not cause any degradation in the structural metals (aluminum, steel etc.). With $0.01-0.05 \mathrm{mg} / 1$ ozone in the system, biofilm formation can be prevented, $\sim 0.2 \mathrm{mg} / 1$ of ozone is sufficient to protect a system from organic contamination, and $0.2-1 \mathrm{mg} / 1$ of ozone are required to clean the system with biological deposits (biofouling) [55]. Also, ozone is more cost effective with a better cost/effective ratio than chlorine and bromine.

\section{Hydrogen peroxide}

Hydrogen peroxide is relatively a cheaper and stable biocide, and it is usually applied when metals are exposed to water for longer periods of time. It is reported that $50-100 \mathrm{ppm}$ concentration of hydrogen peroxide can effectively inhibit the microbial growth and biofilm formation in the system [55].

\subsubsection{Non-oxidizing biocides}

Non-oxidizing biocides used more than the oxidizing biocides because they are more effective in the eradication of fungi, algae and bacteria. Unlike oxidizing biocides, they are independent of $\mathrm{pH}$ [55]. Following are the mostly used biocides for treating MIC problems. 


\section{Glutaraldehyde}

Glutaraldehyde is in integral component of many biocides due to its stability over a large $\mathrm{pH}$ and temperature ranges. The chemical is highly effective in treating sulphate reducing bacteria in biofilms, where the main reaction is between the functional group of glutaraldehyde and the proteins in the cell membrane, cell walls and cytoplasm [55]. Glutaraldehyde may cause compatibility issues with the system being treated owing to its soluble and insoluble nature in water and oil respectively. A typical concentration of glutaraldehyde, as specified by United State Environmental Protection Agency (USEPA), should not exceed $50 \mathrm{ppm}$ to prevent its adverse impact on the environment.

\section{Quarternary ammonium compounds}

Quarternary ammonium compounds (QUATS) are positively charged biocides and corrosion inhibitors which behaves as detergents, and prevents the polysaccharide formation during the biofilm formation [55]. Generally QUATS are diluted by water, hydroxides and alcohols which improves there penetration capacity and biocidal properties. QUATS are reported to be biodegradable and thus requires no chemical deactivation after their use.

\section{Isothiazolones}

Isothiazolones are mainly composed of oxygen, nitrogen and sulphur, and are popular or their biocidal control of sulphate reducing bacteria. They can be used over a large $\mathrm{pH}$ range and poses no challenges in terms of compatibility with other chemicals. Isothiazolones are popular in controlling the biofilm development of both bacteria and algae due to higher control over the microbial growth and their metabolism.

Some other non-oxidizing biocides may include methylene-bisthiocyanate (MBT), tetrakishydroxymethyl phosphonium sulfate (THPS) etc.

\subsection{Coatings}

The use of coatings to prevent corrosion is substantial, in particular for MIC problems, these coatings are done by non-toxic compounds such as epoxy resins, silicon, and other fluorinated compounds [55]. One problem associated with the use of coating is it should be continuous, which means that coatings should not have any flaws or defects that can make it more vulnerable to localized corrosive attack [59,60]. Two important factors while selecting coating material are: (a) high resistance to bacterial attack and (b) no corrosion products as a result of coating degradation. Based on experiments, Videla et al. reported that epoxy and coal tar coatings are more protective compared to PVC-based coatings [61]. Also, cement linings could be protective against MIC, however, these coatings can be attacked by sulphate oxidizing bacteria [16].

\subsection{Material selection}

Corrosion problems can be minimized to a great extent through proper material selection. For MIC occurrences where the attack is usually localized, the first material section criteria 
is its high resistance to localized corrosion such as pitting and crevice. Borenstein [62] demonstrated several factors that can affect the service life of material exposed to MIC, some of which are design specifications of constructional materials, fabrication process, operation and maintenance, and environmental conditions [63]. It is emphasized that proper material selections must be coupled with an appropriate design, for example, the system design should not promote corrosion through crevices, stagnant conditions, and inappropriate drainage. Moreover, even with the proper material selection, the supplementary measures against MIC are always necessary, such as coating, biocides, inhibitors, and cathodic protection etc.

\subsection{Cathodic protection}

Cathodic protection prevents corrosion through an external current applied to the structure being protected. An explanation of cathodic protection in MIC is that cathodic protection increases the $\mathrm{pH}$ at metal solution interface which causes the hydroxyl ions to release and decrease the solubility of calcium and magnesium compounds [7]. Consequently, calcareous deposits are formed, providing a scale that reduces the amount of current input required for cathodic protection and thus the process become cost effective. Also, the resulting high $\mathrm{pH}$ is intolerable by the microorganisms and thus MIC can be minimized [64].

Videla et al. [55] studied the cathodic protection for MIC and provided come insights about the process of protection. It was reported that the protection begins with the interaction between biofilm and inorganic deposits which modify the biofilms structure together with alterations in the distribution of calcareous deposits. Next, it adjusts the amount of current for adequate protection. Predominantly cathodic protection is found more effective against aerobic bacteria, and a combination of coatings with cathodic protection can greatly contribute to the prevention MIC problems in oils and gas production and transportations facilities such as offshore platforms and buried pipe lines under in corrosive soil environment.

\section{Case studies on MIC in oil and gas industries}

\subsection{Development of molecular microbiology methods for MIC risk assessment (Saudi} Aramco's Research and Development Center)

Saudi Aramco's Research and Development Center (R\&DC) presented their initial findings on a joint project with Danish Technological Institute (DTI), the purpose of which was to develop molecular microbiological methods (MMM) for analyzing the failures and MIC risks in Saudi Aramco's crude oil pipeline systems [65]. A flow of the study is presented in the form of block diagrams in Figure 7(a) and (b). For brevity, only main components of methodology and approach, and results and discussions are included and readers are referred to Al-Saleh et al. [65] for details.

Several tasks were determined as potential future work towards the MIC risk assessment using MMM, which are as follows. 
- To overcome the challenges in extracting the microbial cells from the oil matrix by careful handling of samples

- Development of quantitative polymerase chain reaction (qPCR) to track different microorganisms such as sulphate reducing bacteria and methane producing bacteria etc.

- Estimation of MIC risk factor based on number of microbial cells

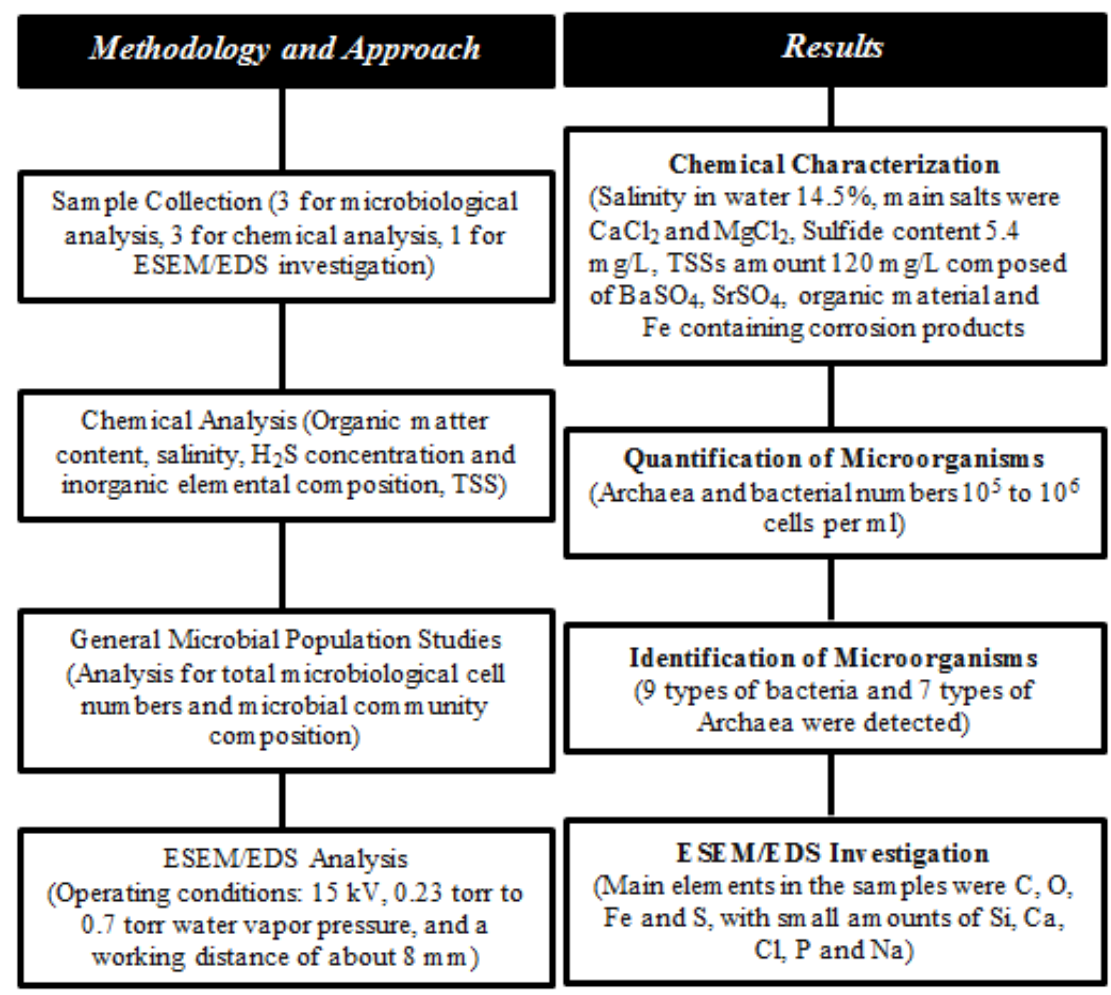

Figure 7. Elements of the development of MMM for MIC risk assessment in crude oil pipeline [65].

\subsection{Proliferation of bacteria by inhibitor degradation (Central Electrochemical Research Institute-CECRI, India)}

Maruthamuthu et al. studied the MIC problems in a $680 \mathrm{~km}$ long pipeline transporting petroleum products across the India [66]. MIC occurrences were observed even in the presence of a corrosion inhibitor (Unicor J). It was reported that the degradation of inhibitor was main reason of bacteria proliferation. Therefore, selection of corrosion inhibitor was also included in the study. Experimental materials and methods and key results are presented in the form of block diagrams in Figure 8(a) and (b), based on the data reported in [66]. 


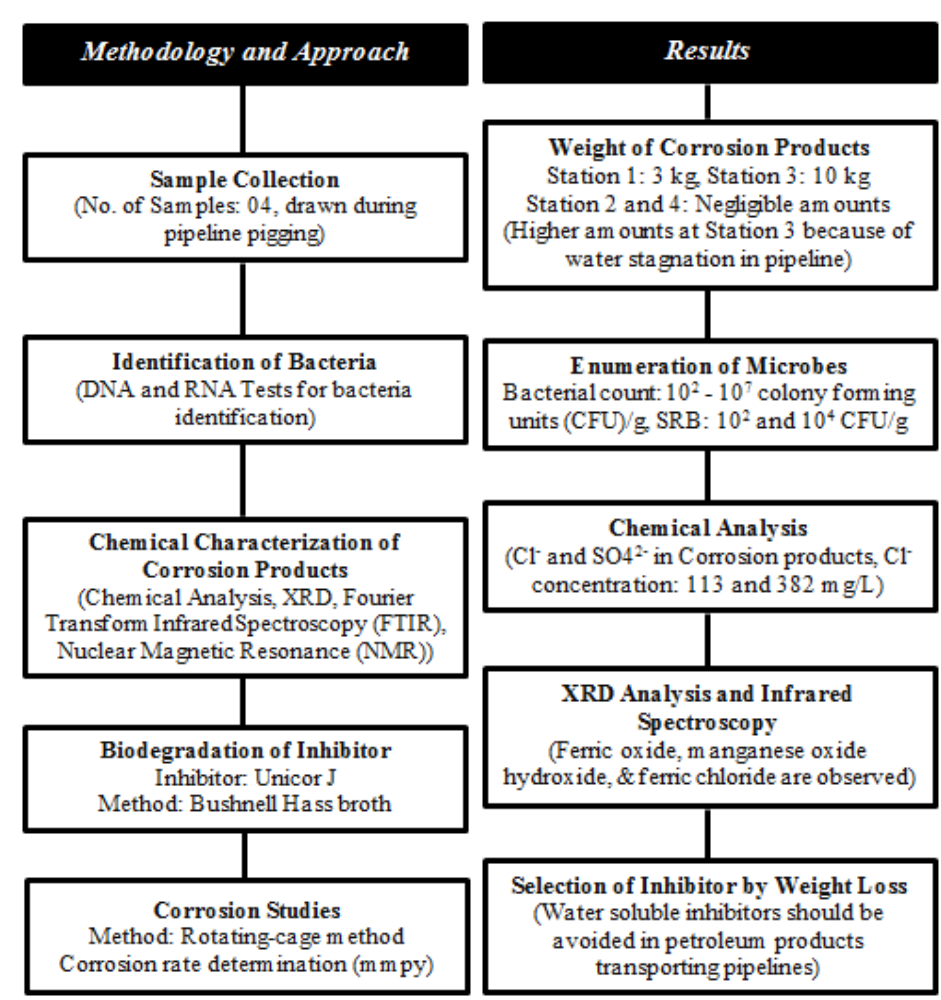

Figure 8. Elements of study on MIC by Central Electrochemical Research Institute-CECRI, India [66].

\section{Conclusions}

This paper is focused on one of the most important type of corrosion i.e. microbiologically influenced corrosion in oil and gas industries. Microorganisms and mechanisms of MIC have been studied, together with monitoring and inspection methods to detect MIC, and prevention and control methods to protect systems from MIC. The study confirms that MIC is a function of a host of parameters, which makes a system vulnerable to MIC. Figure 9 presents a cause and effect diagram of MIC in a pipeline carrying fluids such as oil, gas or water, provided with coating and cathodic protection. It can be observed that a huge set of parameters needs to be considered while dealing with a MIC occurrence. Excerpts from case studies have been presented to emphasize the need of research and development activities on MIC in oil and gas industry. MIC is electrochemical in essence. However, it does not have a straightforward electrochemistry. For more than seven decades, researchers have been trying to explain MIC with electrochemistry, but it seems that the bacteria have more surprises in store for us: while the classic theory proposed in the mid-1930's put all the blame on SRB, the alternative, new theories tried to sequester the bacteria as much as possible. It was recently suggested that perhaps the bacteria themselves are engaged in picking up the required electrons directly from the metallic surface. However, these new findings need to be further examined to explore the complexities encountered in practice more efficiently. SRB are not the only bacteria, or even the most important bacteria, involved in MIC. There are many bacteria that could be much more interesting than SRB. Although SRB and their 
corrosive effects and (for the first time) their impact on stress corrosion cracking were discussed here, another examples of the bacteria involved in corrosion were also presented. Despite what we know about micro-organisms and their role in corrosion, we must be humble and honest to say that these tiny little living things do have the power of puzzling us. Comparing what we know about them with what we do not know is like comparing a single grain of sand with the beach. It is very crucial to learn more about MIC and how it affects our industrial systems, because of the risks involved, both economic and environmental. Logically, in order to know more, much better conditions of research and development are required, and to achieve this, more funding is essential. To attract more funding, apart from considering economic and environmental risks, industry needs to know how systems can be become vulnerable to MIC, as prevention is much better than mitigation.

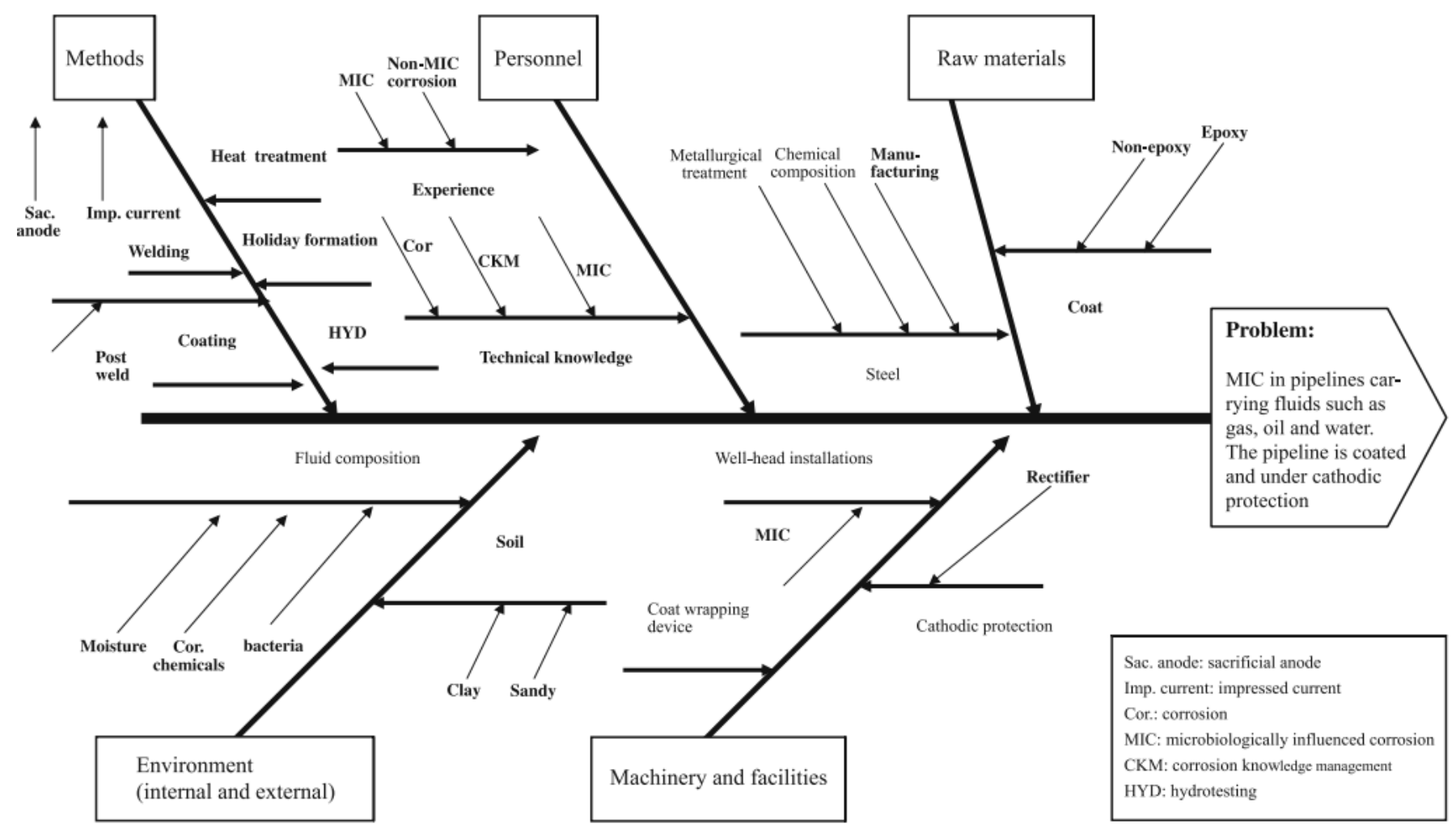

Figure 9. Cause and effect diagram for an MIC problem in pipeline [7].

\section{References}

1. E. McCafferty, Introduction to Corrosion Science, Springer New York, 2010.

2. L. Popoola, A. Grema, G. Latinwo, B. Gutti and A. Balogun, Corrosion problems during oil and gas production and its mitigation, Int. J. Ind. Chem., 2013, 4, no. 1, 35. doi: $\underline{10.1186 / 2228-5547-4-35}$

3. M.J. Franklin, D.C. White and H.S. Isaacs, Pitting corrosion by bacteria on carbon steel, determined by the scanning vibrating electrode technique, Corros. Sci., 1991, 32, no. 9, 945-952. doi: 10.1016/0010-938X(91)90014-G 
4. R. Sandoval-Jabalera et al., Electrochemical behaviour of 1018, 304 and 800 alloys in synthetic wastewater, J. Mex. Chem. Soc., 2006, 50, no. 1, 14-18.

5. W. Sand, Microbial mechanisms of deterioration of inorganic substrates - A general mechanistic overview, Int. Biodeterior. Biodegrad., 1997, 40, no. 2-4, 183-190, doi: 10.1016/S0964-8305(97)00048-6

6. R. Javaherdashti and R.K. Raman, Microbiologically - influenced corrosion of stainless steels in Marine environments: A materials engineering approach, 2001.

7. R. Javaherdashti, Microbiologically influenced corrosion: an engineering insight, 2008.

8. F.M. AlAbbas, A. Kakpovbia, D.L. Olson, B. Mishra and J.R. Spear, The role of bacterial attachment to metal substrate and its effects on microbiologically influenced corrosion (MIC) in transporting hydrocarbon pipelines, 2012, no. I, 131-144.

9. R. Singleton, The sulfate-reducing bacteria: An overview BT - The sulfate-reducing bacteria: Contemporary perspectives, Springer New York, 1993, 1-20.

10. S. Maxwell, C. Devine and F. Rooney, Monitoring and control of bacterial biofilms in oilfield water handling systems, CORROSION 2004, NACE International, New Orleans, Louisiana, 2004, 16.

11. M. de Romero, Z. Duque, O. de Rincón, O. Pérez, I. Araujo and A. Martinez, Online monitoring systems of microbiologically influenced corrosion on $\mathrm{Cu}-10 \% \mathrm{Ni}$ alloy in chlorinated, brackish water, Corrosion, 2000, 56, no. 8, 867-876. doi: $\underline{10.5006 / 1.3280590}$

12. S.Y. Li, Y.G. Kim, Y.T. Kho and T. Kang, Corrosion behavior of carbon steel influenced by sulfate reducing bacteria in soil environments, CORROSION 2003, NACE International, San Diego, California, 2003, 20.

13. F. Sarioğlu, R. Javaherdashti and N. Aksöz, Corrosion of a drilling pipe steel in an environment containing sulphate-reducing bacteria, Int. J. Press. Vessel. Pip., 1997, 73, no. 2, 127-131, doi: 10.1016/s0308-0161(97)00022-7

14. M. de Romero, S.C. Urdaneta, M. Barrientos and G. Romero, Correlation between desulfovibrio sessile growth and OCP, hydrogen permeation, corrosion products and morphological attack on iron, CORROSION 2004, NACE International, New Orleans, Louisiana, 2004, 27.

15. B. Little and P. Wagner, Myths related to microbiologically influenced corrosion, 1997, [Online]. Available: https://www.osti.gov

16. N. Muthukumar et al., Microbiologically influenced corrosion in petroleum product pipelines - A review, Indian J. Exp. Biol., 2003, 41, no. 9, 1012-1022.

17. I. Beech, A. Bergel, A. Mollica, H.-C. Flemming, V. Scotto and W. Sand, Simple methods for the investigation of the role of biofilms in corrosion, European Federation of Corrosion.

18. L.L. Barton and F.A. Tomei, Characteristics and activities of sulfate-reducing bacteria BT - Sulfate-reducing bacteria, MA: Springer US, 1995, 1-32.

19. G. Hernandez, V. Kucera, D. Thierry, A. Pedersen and M. Hermansson, Corrosion inhibition of steel by bacteria, Corrosion, 1994, 50, no. 08, 6 . 
20. C. Kühr and L.S.V.D. Vlugt, Graphitization of cast iron as an electrobiochemical process in anaerobic soils, 1964.

21. C.G. Friedrich, D. Rother, F. Bardischewsky, A. Ouentmeier and J. Fischer, Oxidation of reduced inorganic sulfur compounds by bacteria: Emergence of a common mechanism?, Appl. Environ. Microbiol., 2001, 67, no. 7, 2873-2882. doi: 10.1128/AEM.67.7.2873-2882.2001

22. J.R. Lloyd, Microbial reduction of metals and radionuclides, FEMS Microbiol. Rev., 2003, 27, no. 2-3, 411-425. doi: 10.1016/S0168-6445(03)00044-5

23. V.K. Singh, A.L. Singh, R. Singh and A. Kumar, Iron oxidizing bacteria: insights on diversity, mechanism of iron oxidation and role in management of metal pollution, Environ. Sustain., 2018, 1, no. 3, 221-231. doi: 10.1007/s42398-018-0024-0

24. R.A. Lane, Under the microscope: Understanding, detecting, and preventing microbiologically influenced corrosion, J. Fail. Anal. Prev., 2005, 5, no. 5, 10-12. doi: 10.1361/154770205X65891

25. M. Schütze, Corrosion books: Corrosion mechanisms in theory and practice, Mater. Corros., 2003, 54, no. 6, 467-468. doi: 10.1002/maco.200390104

26. H. Castaneda and X.D. Benetton, SRB-biofilm influence in active corrosion sites formed at the steel-electrolyte interface when exposed to artificial seawater conditions, Corros. Sci., 2008, 50, no. 4, 1169-1183. doi: 10.1016/j.corsci.2007.11.032

27. J.A. Costello, Cathodic depolarization by sulphate reducing bacteria, S. Afr. J. Sci., 1974, 70, no. 7, 202-204.

28. S. Kakooei, M.C. Ismail, B. Ariwahjoedi and B.S. Iskandar, Mechanisms of microbiologically influenced corrosion : A review, World Appl. Sci. J., 2017, 17, no. 4, 524-531.

29. K. Mori, H. Tsurumaru and S. Harayama, Iron corrosion activity of anaerobic hydrogenconsuming microorganisms isolated from oil facilities, J. Biosci. Bioeng., 2010, 110, no. 4, 426-430. doi: 10.1016/j.jbiosc.2010.04.012

30. D. Hang, Microbiological study of the anaerobic corrosion of iron, 2003, 98 [Online]. Available: http://elib.suub.uni-bremen.de

31. R.A. King and J.D.A.Miller, Corrosion by the sulphate-reducing bacteria, Nature, 1971, 233, no. 5320, 491-492. doi: $10.1038 / 233491 \mathrm{a} 0$

32. H.A. Videla, An overview of mechanisms by which sulphate-reducing bacteria influence corrosion of steel in marine environments, Biofouling, 2000, 15, no. 1-3, 37-47. doi: $\underline{10.1080 / 08927010009386296}$

33. L.R. Hilbert, T. Hemmingsen, L.V. Nielsen and S. Richter, When can electrochemical techniques give reliable corrosion rates on carbon steel in sulfide media?, CORROSION 2005, NACE International, Houston, Texas, 2005, 20.

34. R.A. King, J.D.A. Miller and J.S. Smith, Corrosion of mild steel by iron sulphides, $B r$. Corros. J., 1973, 8, no. 3, 137-141. doi: 10.1179/000705973798322251

35. W. Lee and W.G. Characklis, Corrosion of mild steel under anaerobic biofilm, Corrosion, 1993, 49, no. 3, 14. 
36. W.P. Iverson, Corrosion of iron and formation of iron phosphide by desulfovibrio desulfuricans, Nature, 1968, 217, no. 5135, 1265-1267. doi: $10.1038 / 2171265 \mathrm{a} 0$

37. W.P. Iverson, Research on the mechanisms of anaerobic corrosion, Int. Biodeterior. Biodegrad., 2001, 47, no. 2, 63-70. doi: 10.1016/S0964-8305(00)00111-6

38. C.O. Obuekwe, D.W.S. Westlake, J.A. Plambeck and F.D. Cook, Corrosion of mild steel in cultures of ferric iron reducing bacterium isolated from crude oil I. Polarization characteristics, Corrosion, 1981, 37, no. 8, 461-467. doi: 10.5006/1.3585992

39. J. Crolet, Biocorrosion: $\mathrm{pH}$ regulation by sulfate-reducing bacteria, 1992.

40. T.C. de Araujo-Jorge, C.M.L.M. Coutinho and L.E.V. de Aguiar, Sulphate-reducing bacteria associated with biocorrosion: A review, Mem. Inst. Oswaldo Cruz, 1992, 87, no. 3. 329-337. doi: $10.1590 / \mathrm{s} 0074-02761992000300001$

41. T. Ford and R. Mitchell, The ecology of microbial corrosion BT - Advances in microbial ecology, MA: Springer US, 1990, 231-262.

42. H.-C. Flemming and G.G. Geesey, Biofouling and biocorrosion in industrial water systems, Springer, Berlin, Heidelberg, 1990. doi: 10.1007/978-3-642-76543-8

43. H. Wang and C. hao Liang, Effect of sulfate reduced bacterium on corrosion behavior of 10CrMoAl steel, J. Iron Steel Res. Int., 2007, 14, no. 1, 74-78. doi: 10.1016/S1006706X(07)60016-8

44. I.B. Beech, C.W.S. Cheung, D.B. Johnson and J.R. Smith, Comparative studies of bacterial biofilms on steel surfaces using atomic force microscopy and environmental scanning electron microscopy, Biofouling, 1996, 10, no. 1-3, 65-77. doi: $10.1080 / 08927019609386271$

45. I.B. Beech, Corrosion of technical materials in the presence of biofilms - Current understanding and state-of-the art methods of study, Int. Biodeterior. Biodegrad., 2004, 53, no. 3, 177-183. doi: 10.1016/S0964-8305(03)00092-1

46. H.H.P. Fang, L.C. Xu and K.Y. Chan, Effects of toxic metals and chemicals on biofilm and biocorrosion, Water Res., 2002, 36, no. 19, 4709-4716. doi: 10.1016/S00431354(02)00207-5

47. H.H.P. Fang, L.-C. Xu and K.-Y. Chan, Influence of $\mathrm{Cr}^{3+}$ on microbial cluster formation in biofilm and on steel corrosion, Biotechnol. Lett., 2000, 22, no. 9, 801-805. doi: 10.1023/A:1005620606868

48. K.Y. Chan, L.C. Xu and H.H.P. Fang, Anaerobic electrochemical corrosion of mild steel in the presence of extracellular polymeric substances produced by a culture enriched in sulfate-reducing bacteria, Environ. Sci. Technol., 2002, 36, no. 8, 1720-1727. doi: $10.1021 / \mathrm{es} 011187 \mathrm{c}$

49. H.A. Videla, Microbially induced corrosion: An updated overview, Int. Biodeterior. Biodegrad., 2001, 48, no. 1-4, 176-201. doi: 10.1016/S0964-8305(01)00081-6

50. B.J. Little, R.I. Ray and R.K. Pope, Relationship between corrosion and the biological sulfur cycle: A review, Corrosion, 2000, 56, no. 4, 13. 
51. M. de Romero, The mechanism of SRB action in MIC, based on sulfide corrosion and iron sulfide corrosion products, CORROSION 2005, NACE International, Houston, Texas, 2005, 30.

52. L. Ocando et al., Evaluation $\mathrm{Of} \mathrm{Ph}$ And $\mathrm{H}_{2} \mathrm{~S}$ on biofilms generated by sulfate-reducing bacteria: Influence of ferrous ions, CORROSION 2007, NACE International, Nashville, Tennessee, 2007, 18.

53. T. Gu, K. Zhao and S. Nesic, A new mechanistic model for MIC based on a biocatalytic cathodic sulfate reduction theory, CORROSION 2009, NACE International, Atlanta, Georgia, 2009, 12.

54. B. Little, J. Lee and R. Ray, New developments in mitigation of microbiologically influenced corrosion, 2007, 8.

55. H.A. Videla, Prevention and control of biocorrosion, Int. Biodeterior. Biodegrad., 2002, 49, no. 4, 259-270. doi: 10.1016/S0964-8305(02)00053-7

56. R. Kashkovskiy, K. Strelnikova and A. Fedotova, Application of electrochemical impedance spectroscopy to study hydrogen sulphide corrosion of steel and its inhibition: a review, Corros. Eng. Sci. Technol., 2019, 54, no. 6, 493-515. doi: 10.1080/1478422X.2019.1619979

57. P. Stokes, M. Winters, P. Zuniga and D. Schlottenmier, Developments in on-line fouling and corrosion surveillance, West Conshohocken, PA: ASTM International, 1994, 99107. doi: $10.1520 /$ STP12927S

58. G.J. Licina, Monitoring biofilms on metallic surfaces in real time, CORROSION 2001, NACE International, Houston, Texas, 2001, 23.

59. R. Javaherdashti and P. Vimpani, Corrosion of steel piles in soils containing SRB: a review, 2003.

60. C.A. Metosh-Dickey, R.J. Portier and X.I.E. Xiaogang, A novel surface coating incorporating copper metal flakes for reducing biofilm attachment, Mater. Perform., $2004, \mathbf{4 3}$, no. $10,30-34$.

61. H.A. Videla, Manual of biocorrosion, Routledge, 2018.

62. S.W. Borenstein and P.B. Lindsay, Microbiologically influenced corrosion failure analysis of 304L stainless steel piping system left stagnant after hydrotesting with city water, CORROSION 2002, NACE International, Denver, Colorado, 2002, 10.

63. S.W. Borenstein, Introduction to microbiologically influenced corrosion, Woodhead Publishing, 1994, 1-7.

64. M. de Romero et al., Cathodic Polarization Effect on Sessile SRB growth and iron protection, CORROSION 2006, NACE International, San Diego, California, 2006, 22.

65. M.A. Al-Saleh, P.F. Sanders, T.M. Ibrahim, K.B. Sørensen, T. Lundgaard and S. Juhler, Microbially influenced corrosion assessment in crude oil pipelines, CORROSION 2011, NACE International, Houston, Texas, 2011, 10.

66. S. Maruthamuthu et al., Microbial corrosion in petroleum product transporting pipelines, Ind. Eng. Chem. Res., 2011, 50, no. 13, 8006-8015. doi: 10.1021/ie1023707 